Report

\title{
The somatostatin analog Sandostatin (SMS201-995) in treatment of DMBA-induced rat mammary tumors
}

\author{
G.H. Bakker, B. Setyono-Han, J.A. Foekens, H. Portengen, W.L.J. van Putten ${ }^{1}$, F.H. de Jong ${ }^{2}$, \\ S.W.J. Lamberts ${ }^{3}$, J.C. Reubi ${ }^{4}$ and J.G.M. Klijn \\ Division of Endocrine Oncology (Biochemistry and Endocrinology) and ${ }^{I}$ Department of Statistics, \\ The Dr. Daniel Den Hoed Cancer Center, Rotterdam; the Departments of ${ }^{2}$ Biochemistry \\ (Chemical Endocrinology) and ${ }^{3}$ Internal Medicine, Erasmus University, Rotterdam, The Netherlands; \\ and ${ }^{4}$ Sandoz Research Institute, Bern, Switzerland
}

Key words: buserelin, LHRH-agonists, rat mammary tumor, sandostatin, somatostatin analogs

\section{Summary}

The effects of treatment with a somatostatin analog (Sandostatin, SMS201-995) were investigated in female rats with dimethylbenzanthracene(DMBA)-induced rat mammary tumors. A 3-week treatment was performed using sandostatin, the LHRH-agonist buserelin alone, or buserelin in combination with sandostatin. Twice daily sandostatin treatment was performed with dosages of $0.05 \mu \mathrm{g}, 0.2 \mu \mathrm{g}, 1 \mu \mathrm{g}, 5 \mu \mathrm{g}$, and $20 \mu \mathrm{g}$. Buserelin was used in a $2 \times 5 \mu \mathrm{g} /$ day dosage.

The combined results from six different experiments show that the various dosages of sandostatin caused no tumor growth inhibition. Somatostatin receptors could not be demonstrated in these mammary tumors. Sandostatin treatment by daily injections did not suppress levels of growth hormone, prolactin, or epidermal growth factor-like activities. Estrogen (ER) and progesterone (PgR) receptor contents of the mammary tumors were not changed. In contrast, buserelin treatment caused highly significant tumor remission. The combined treatment with sandostatin and buserelin did not alter the treatment results obtained after treatment with buserelin alone.

In conclusion, sandostatin treatment in this tumor model had no direct growth inhibitory effect and did not cause an endocrine inhibition of mammary tumor growth. However, these results do not exclude antitumor effects in human breast cancer in view of the presence of somatostatin receptors in approximately $20-45 \%$ of human tumors, besides possible different endocrine effects.

\section{Introduction}

Endocrine treatment of metastatic breast cancer is aimed at decreasing plasma concentrations of growth stimulatory hormones or factors, or at antagonizing the biological effects of these hormones and factors directly. The involvement of prolactin
(PRL) and growth hormone (GH) in growth regulation of human breast cancer cells is still unclear, although numerous experimental data obtained with rodents support the contention that PRL is important in growth and development of their mammary tumors [e.g. 1-3]. The binding of human GH to the lactogenic receptor of human breast 
cancer cells in vitro and in vivo may also cause growth stimulatory effects [4-7]. The observation of increased plasma levels of GH and PRL in breast cancer patients [8] may therefore be associated with a poorer prognosis compared to patients with low hormone levels, as described for $\mathrm{GH}$ in prostate cancer patients [9].

Furthermore, GH can increase plasma levels and local production of insulin-like growth factor-1 (IGF-1 or somatomedin C) [10-14]. IGF-1 and estradiol $\left(\mathrm{E}_{2}\right)$ are the most potent growth stimulatory agents for human breast cancer cells in vitro (for a review, see ref. 15). IGF-1 and epidermal growth factor (EGF) appear to be autocrine and paracrine growth factors for human breast cancer cells [15]. Recently, significant levels of IGF-1 receptors were demonstrated in more than $90 \%$ of human primary breast tumors [16-19]. Therefore, inhibition of GH secretion (and possibly that of IGF-1 and EGF) by administration of somatostatin and its analogs may be a means for inhibiting breast cancer growth.

We found that somatostatin receptors are present in $15-19 \%$ of primary breast tumor specimens $[19,20]$. Moreover, we have previously described the presence of somatostatin receptors in MCF-7 human breast cancer cells, and the growth inhibition of these cells caused by sandostatin [21]. The results from two first experiments with rat DMBAinduced mammary tumors suggested in vivo growth inhibition caused by sandostatin, besides additive inhibitory effects of sandostatin and the LHRH-agonist buserelin [22]. Combined treatment with buserelin and sandostatin was studied to find out whether the addition of sandostatin might improve the tumor remission observed after buserelin treatment alone [e.g. 23].

Therefore, we have studied more extensively the possible direct and indirect (endocrine) growth inhibitory effects of chronic sandostatin treatment of female rats bearing mammary tumors, as a single agent or in combination with buserelin.

\section{Materials and methods}

Female rats of the Sprague-Dawley strain were obtained from the Zentralinstitut fur Versuchstier- zucht, Hannover, F.R.G. Rats were kept four to a cage under controlled light conditions (light on: 8:00 AM; light off: 7:00 PM) on wood shavings and received standard dry pellets (Hope Farms, Woerden, The Netherlands) and tap water ad libitum.

\section{Hormonal agent solutions}

The somatostatin analog sandostatin (SMS201995) was kindly supplied by Sandoz Ltd., Basel, Switzerland, in a stock solution of $0.1 \mathrm{mg} / \mathrm{ml}$. The LHRH-agonist buserelin was kindly provided by Hoechst A.G., Frankfurt am Main, F.R.G., in a stock solution of $1 \mathrm{mg} / \mathrm{ml}$. Work solutions were made by dilution of the stock solutions with $0.15 \mathrm{M}$ $\mathrm{NaCl}$. Twice-daily subcutaneous injections of sandostatin or buserelin solution were administered in a volume of $100 \mu \mathrm{l}$ around 9:00 AM and 5:00 PM. Control animals received daily injections of $100 \mu \mathrm{l}$ saline. Final daily dosages per rat were: for sandostatin $2 \times 0.05 \mu \mathrm{g}, 2 \times 0.2 \mu \mathrm{g}, 2 \times 1 \mu \mathrm{g}$, $2 \times 5 \mu \mathrm{g}$ and $2 \times 20 \mu \mathrm{g}$; for buserelin $2 \times 5 \mu \mathrm{g}$ (i.e. $40 \mu \mathrm{g} / \mathrm{kg} / \mathrm{day})$. The highest sandostatin dosage used was that described by Lamberts et al. [24]. In view of the desensitization reported by them, we decided to use lower sandostatin dosages to try to circumvent possible desensitization phenomena. Combined treatment with sandostatin and buserelin involved separate injections of either hormonal agent solution, at distant loci on the back of the rat.

\section{Tumor induction}

Dimethylbenzanthracene (DMBA, Fluka, Basel, Switzerland) was dissolved in olive oil at a concentration of $10 \mathrm{mg} / \mathrm{ml}$. The solution obtained was stored in the dark. Induction of mammary tumors was performed with 2 intragastric administrations of $1 \mathrm{ml}$ of DMBA-solution given with a 7-day interval to 54-61 day old rats [25].

\section{Start of treatments}

Animals were palpated twice weekly to detect the 
presence of mammary tumors. In total, six different experiments were performed. An overview of the experimental treatments as well as the number of rats used in the different treatment groups in the separate experiments is presented in Table 1 . It was impossible to collect data from all rats for each parameter for several reasons: untimely death of some rats, lack of enough tumor tissue after treatment, or insufficient amount of blood plasma. Treatment began when all rats had palpable tumors (105-115 days of age). In studying treatment effects on growth of these rat mammary tumors, we have found that some tumors may regress and some remain stable while other tumors progress, all on the same rat, and to some extent even in control rats. Therefore, we decided to use the total tumor load per rat to compare the treatment results on tumor growth. Rats were anaesthetized with diethyl ether, and the size of the individual tumors was measured with calipers and calculated as the product of the two largest perpendicular diameters. For each rat, the sum of the individual tumor areas was taken as the tumor load of the animal. Rats were divided between control and treatment groups (711 rats per group; equal numbers in the different groups in an individual experiment) in such a way that the same average tumor load was obtained in each group.

\section{End of treatments}

After treatment for 3 weeks, the tumor load was estimated again in anaesthetized rats. The next day, the last injections were given around 9:00 $\mathrm{AM}$, and the animals were killed by decapitation without diethyl ether anaesthesia. Rats were killed one by one taking rats from the different treatment groups in succession. Blood was collected in heparinized tubes and in tubes with EDTA-solution. Plasma was stored at $-20^{\circ} \mathrm{C}$ until assay for $\mathrm{GH}$, PRL, luteinizing hormone ( $\mathrm{LH})$, follicle stimulating hormone (FSH), $\mathrm{E}_{2}$, insulin, and EGF-like activities. Tumor tissue was collected and stored at $-70^{\circ} \mathrm{C}$ until assay for estrogen (ER) and progesterone receptor $(\mathrm{PgR})$. Finally, the weights of the pituitary and adrenal glands, and of the ovaries, uterus, and pancreas, were recorded.

\section{Steroid receptor and somatostatin receptor assays}

Assay of cytosolic ER and PgR were performed by multiple-point Scatchard analysis, according to the procedures recommended by the EORTC for the measurement of ER and $\mathrm{PgR}$ in the cytosol of human breast tumor biopsies [26]. Somatostatin receptors were measured by autoradiography on

Table 1. Overview of the experimental treatment groups and the number of rats used in the separate experiments

\begin{tabular}{|c|c|c|c|c|c|c|c|}
\hline \multirow[t]{2}{*}{ Treatment } & \multicolumn{6}{|c|}{ Experiment number } & \multirow{2}{*}{$\begin{array}{l}\text { Total number } \\
\text { of rats }\end{array}$} \\
\hline & 1 & 2 & 3 & 4 & 5 & 6 & \\
\hline Control & 5 & 7 & 8 & 7 & 10 & 8 & 45 \\
\hline \multicolumn{8}{|l|}{ Sandostatin: } \\
\hline $2 \times 0.05 \mu \mathrm{g}$ & - & - & 8 & 7 & - & 8 & 23 \\
\hline $2 \times 0.2 \mu \mathrm{g}$ & - & - & 8 & 7 & - & 8 & 23 \\
\hline $2 \times 1 \mu \mathrm{g}$ & 5 & 7 & 8 & 7 & - & - & 27 \\
\hline $2 \times 5 \mu \mathrm{g}$ & 7 & 7 & - & - & - & 7 & 21 \\
\hline $2 \times 20 \mu \mathrm{g}$ & 8 & 8 & - & 7 & - & - & 23 \\
\hline \multicolumn{8}{|l|}{ Buserelin: } \\
\hline $2 \times 5 \mu \mathrm{g}$ & 7 & 8 & 6 & - & 11 & - & 32 \\
\hline \multicolumn{8}{|l|}{ Plus sandostatin: } \\
\hline $2 \times 0.2 \mu \mathrm{g}$ & - & - & - & - & 10 & - & 10 \\
\hline $2 \times 1 \mu \mathrm{g}$ & - & - & 8 & - & 11 & - & 19 \\
\hline $2 \times 20 \mu \mathrm{g}$ & 7 & 8 & - & - & - & - & 15 \\
\hline Total number of rats: & 39 & 45 & 46 & 35 & 42 & 31 & 238 \\
\hline
\end{tabular}




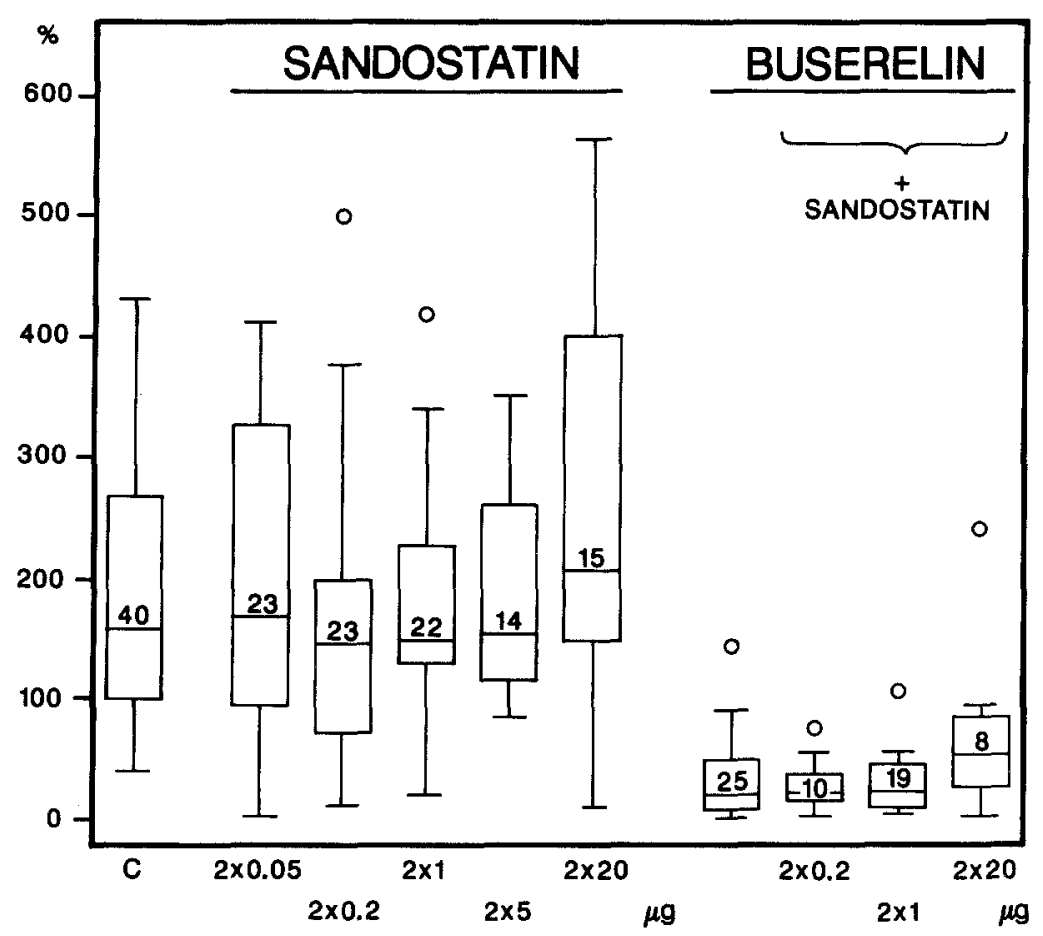

Fig. 1. Box and whisker plot of the effects on relative mammary tumor load after different endocrine treatments for 3 weeks with various dosages of sandostatin (denoted on the $\mathrm{x}$-axis), with buserelin $(2 \times 5 \mu \mathrm{g})$, and different combinations of buserelin and sandostatin. $\mathrm{C}=$ control. Relative tumor load (\%) of a rat in a certain treatment group is defined as the ratio of its tumor load at the end of treatment (in $\mathrm{mm}^{2}$ ) and the average tumor load of the group as a whole (in $\mathrm{mm}^{2}$ ) at the start of treatment, and multiplied by 100 . The boxes denote the interquartile range (from $25-75 \%$ ) of the results obtained. The horizontal line in the box denotes the median group value. Small circles denote outliers. The number of rats used to make this Figure are denoted in the boxes. Initial tumor load $=100 \%$.

$10 \mu \mathrm{m}$ cryostat sections of the tumor tissue as described for other endocrine tumors [27, 28]. Two iodinated somatostatin analogs were used as radioligands, the $\mathrm{Tyr}^{3}$ analog of SMS201-995, codenamed 204-090, [H-(D)Phe-Cys-Tyr-(D)Trp-LysThr-Cys-Thr-(ol)], as well as the SS-28 derivative $\left[\mathrm{Leu}^{8}\right.$, (D)Trp $\left.{ }^{22}, \mathrm{Tyr}^{25}\right]-\mathrm{SS}-28$ (LTT-SS-28). Both analogs have been shown to specifically label somatostatin receptors [29].

\section{Plasma hormone and growth factor assays}

GH and PRL were assayed by radioimmunoassay [24]. Assays of LH and FSH were performed as described by Welschen et al. [30]. Results are expressed in terms of the standards LH RP-1 and FSH RP-1 from the NIAMD. $E_{2}$ was assayed with kits obtained from Diagnostic Products Corporation,
Los Angeles CA, USA. Assay of insulin was performed with a specific radioimmunoassay using a commercially available kit from Incstar, Stillwater, Minnesota, U.S.A. EGF-like activities were assayed by radioreceptor assay after acid-ethanol extraction of the plasma, using human placental membranes as receptor source [18].

\section{Statistical evaluation of results}

The treatment effects of sandostatin and buserelin were analysed with ANOVA (analysis of variance) on the pooled data of the 6 experiments. In the ANOVA the experiment number was included as a nominal variable (6 levels) to correct for systematic differences between the experiments. For most of the endpoints statistically significant differences between experiments were found. This implied 
that inclusion of this factor in the ANOVA was required in order to obtain unbiased estimates of the treatment effects of sandostatin (nominal variable with 6 levels: $0 \mu \mathrm{g}, 2 \times 0.05 \mu \mathrm{g}, 2 \times 0.2 \mu \mathrm{g}, 2 \times$ $1 \mu \mathrm{g}, 2 \times 5 \mu \mathrm{g}, 2 \times 20 \mu \mathrm{g}$ ) and buserelin (nominal variable with 2 levels: $0 \mu \mathrm{g}, 2 \times 5 \mu \mathrm{g}$ ). In case of a very skewed distribution of an endpoint, as was the case with most of the plasma hormone levels, alogarithmic transformation or a square root transformation was performed in order to obtain a more symmetrically distributed variable. The transformed variable was used in the ANOVA.

\section{Results}

\section{Effects of treatments on tumor growth}

The relative effects of chronic treatment with various dosages of sandostatin, with or without buserelin, on rat mammary tumor load are shown in Fig. 1. Sandostatin treatment caused no inhibition of mammary tumor growth. There was no statistically significant difference in tumor load between the groups treated with the different sandostatin dosages and control (ANOVA, $P=0.39$ ). In contrast, the effect of buserelin treatment (average tumor remission of approx. 60\%) was highly significant $(\mathrm{P}<0.0001)$. Tumor remission after combined treatment with buserelin and three sandostatin dosages was not statistically different from that resulting from treatment with buserelin alone.

\section{Effects on all other parameters}

ANOVA showed that treatment with buserelin (with or without sandostatin) had a strong and statistically highly significant effect on almost all of the endpoints studied (Table 2). No effect could be demonstrated on GH, EGF-like activities, or on the weights of the pituitary and the pancreas. Buserelin treatment resulted in a decrease in tumor load, ER, PgR, PRL, $E_{2}$, and the weight of the ovaries and the uterus, besides an increase in $\mathrm{LH}$, FSH, insulin, and the weight of the adrenals. Be-

Table 2. Combined results of sandostatin and buserelin treatment on various parameters

\begin{tabular}{|c|c|c|c|c|}
\hline Parameter & $\begin{array}{l}\text { Combined results from } \\
\text { all animals treated* } \\
\text { without buserelin }(n=162)\end{array}$ & $\begin{array}{l}\text { Combined results from } \\
\text { all buserelin treated } \\
\text { animals }(n=76)\end{array}$ & $\begin{array}{l}\text { Effect of } \\
\text { sandostatin } \\
\text { (P-value) }\end{array}$ & $\begin{array}{l}\text { Effect of } \\
\text { buserelin }^{2} \\
\text { (P-value) }\end{array}$ \\
\hline Relative tumor load (\%) & $194 \pm 117(137)$ & $39 \pm 40(60)$ & 0.51 & $<0.0001$ \\
\hline $\mathrm{ER}(\mathrm{fmol} / \mathrm{mg})$ & $118 \pm 55(95)$ & $61 \pm 49(27)$ & 0.73 & $<0.0001$ \\
\hline $\mathrm{PgR}(\mathrm{fmol} / \mathrm{mg})$ & $359 \pm 276(94)$ & $28 \pm 27(23)$ & 0.90 & $<0.0001$ \\
\hline $\mathrm{GH}(\mu \mathrm{g} / \mathrm{ml})$ & $40 \pm 41(118)$ & $29 \pm 33(43)$ & 0.97 & 0.11 \\
\hline $\operatorname{PRL}(\mu \mathrm{g} / \mathrm{ml})$ & $135 \pm 119(118)$ & $44 \pm 35(43)$ & 0.19 & $<0.0001$ \\
\hline $\mathrm{LH}(\mathrm{ng} / \mathrm{ml})$ & $34 \pm 50(109)$ & $179 \pm 255(41)$ & 0.60 & $<0.0001$ \\
\hline $\mathrm{FSH}(\mathrm{ng} / \mathrm{ml})$ & $101 \pm 63(113)$ & $367 \pm 250(43)$ & 0.55 & $<0.0001$ \\
\hline $\mathrm{E} 2(\mathrm{pmol} / \mathrm{l})$ & $61 \pm 44(115)$ & $42 \pm 23(42)$ & $0.002^{3}$ & $<0.02$ \\
\hline Insulin $(\mathrm{mU} / \mathrm{l})$ & $11 \pm 5(118)$ & $13 \pm 4(43)$ & 0.14 & $<0.0001$ \\
\hline EGF-like activities (ng/ml) & $24 \pm 19(91)$ & $29 \pm 14(29)$ & 0.88 & 0.86 \\
\hline Pituitary (mg) & $15 \pm 3(159)$ & $16 \pm 2(72)$ & 0.38 & 0.88 \\
\hline Adrenals (mg) & $59 \pm 12(160)$ & $73 \pm 16(75)$ & 0.14 & $<0.0001$ \\
\hline Ovaries (mg) & $133 \pm 32(162)$ & $100 \pm 26(75)$ & 0.61 & $<0.0001$ \\
\hline Uterus (mg) & $480 \pm 233(161)$ & $235 \pm 51(75)$ & 0.71 & $<0.0001$ \\
\hline Pancreas (mg) & $1686 \pm 336(87)$ & $1470 \pm 145(7)$ & 0.68 & 0.80 \\
\hline
\end{tabular}

Results are means \pm S.D. (n). * control animals included. ${ }^{1}$ F-test (ANOVA) for the effect of sandostatin corrected for differences between experiments; restricted to animals treated without buserelin. ${ }^{2}$ F-test (ANOVA) for the effect of buserelin corrected for differences between experiments and sandostatin dosages. ${ }^{3} \mathrm{cf}$. Results section. 


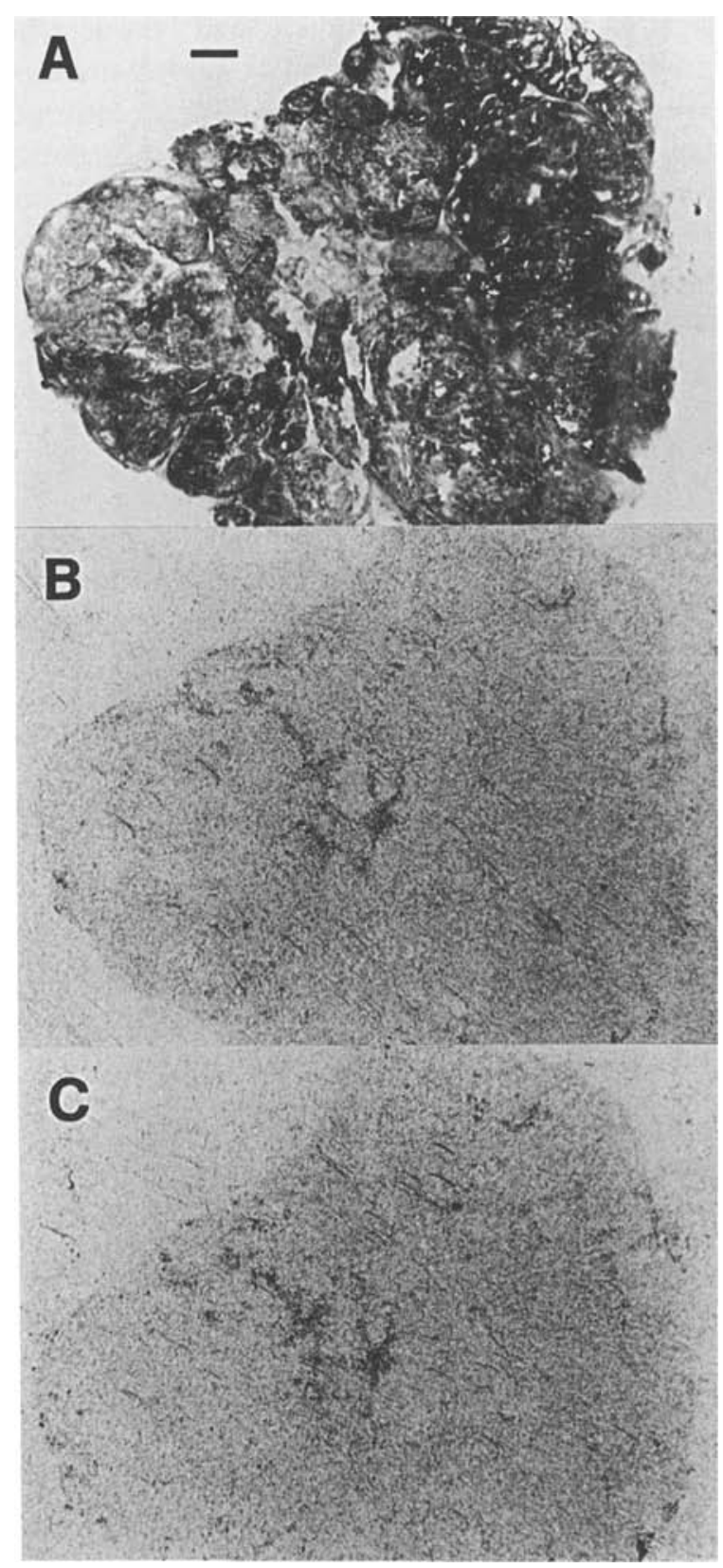

Fig. 2. Lack of somatostatin receptors in a DMBA-induced rat mammary tumor. A: Hematoxylin-eosin stained section. B: Autoradiogram showing total binding of ${ }^{125} \mathrm{I}-\left[\mathrm{Leu}^{8}, \mathrm{D}-\mathrm{Trp}^{22}\right.$, $\mathrm{Tyr}^{25}$ ]-SS-28. C: Autoradiogram showing non-specific binding (in the presence of $10^{-6} \mathrm{M} \mathrm{SS}-28$ ). Exposure time: 1 week using $\left[{ }^{3} \mathrm{H}\right]$-LKB-film (LKB, Rockville, MD., U.S.A.). Bar $=1 \mathrm{~mm}$. cause of these strong effects of buserelin, and as the majority of the animals were treated without buserelin, the effect of sandostatin was tested restricted to the animals treated without buserelin. For none of the endpoints (except for $\mathrm{E}_{2}$ ) was there a statistically significant difference between the 6 sandostatin treatment level groups (control included) (Table 2). The P-values in the table have not been corrected for multiple testing. The sandostatin effect on $E_{2}$ might be due merely to chance fluctuation, in view of the fact that a test for trend was not significant, i.e. there was no evidence for a monotonic relation between the dosage of sandostatin and the mean value of $E_{2}$.

\section{Somatostatin receptors}

No receptors for somatostatin could be demonstrated in any of 7 tumors investigated (Fig. 2).

\section{Discussion}

In contrast to our preliminary observations of inhibitory effects of sandostatin treatment on growth of DMBA-induced rat mammary tumors [22], the present results obtained in a more elaborate in vivo study in female rats showed that sandostatin treatment did not result in growth inhibition of these mammary tumors. For most of the endpoints investigated statistically significant differences between the six experiments were found, but after inclusion of the experiment number to correct for systematic differences between the experiments, no significant effects on tumor growth were determined.

The absence of somatostatin receptors in this tumor model makes it unlikely for direct growth inhibitory effects to occur. This is in contrast to our observations of inhibitory effects of somatostatin analogs on growth of MCF-7 breast cancer cells, which do contain somatostatin receptors [21]. Furthermore, chronic treatment with the different sandostatin dosages was unable to suppress plasma levels of hormones and growth factors of interest, i.e. GH, PRL, insulin, and EGF-like activities. 
This phenomenon might be explained by the development of pituitary desensitization by down-regulation of pituitary somatostatin receptors [24], or by missing short-term endocrine effects, since all animals received their last injections early in the morning whereas actual killing of these animals occurred during the day.

It is difficult to explain the significant decrease in plasma $E_{2}$ levels. This might be due to chance fluctuation, in view of the absence of a monotonic relation between the dosages of sandostatin and the mean values of $E_{2}$, and because of the absence of a significant effect on uterus weight. On the other hand, somatostatin has been reported to inhibit gonadotropin secretion in response to administration of LHRH in normal men [31] and menstruating women [32]. A dissociation between the effects on LHRH-induced LH and FSH secretion was observed, showing only a significantly decreased LH secretion [32]. Furthermore, Schally and Redding [33] reported significantly $(p=0.05)$ decreased testes weights and plasma testosterone levels in rats with Dunning prostate tumors treated with microcapsules containing the somatostatin analog RC-160. These effects on pituitary-gonadal function by somatostatin (analogs) might be explained by effects at the level of the hypothalamus involving catecholamine secretion [32], and/or by direct effects on the gonads [33].

Our results are not in agreement with those reported by other investigators using other experimental mammary tumor models $[12,13,34,35]$. Administration of a somatostatin analog has resulted in regression of nitrosomethylurea-induced rat mammary carcinoma [34], as well as regression of both MT/W9A rat mammary adenocarcinomas [13] and MXT mouse mammary carcinomas [35]. The different results obtained may be due to: 1 . the different tumor models used; 2 . differences in numbers of animals investigated; 3 . the presence or absence of somatostatin receptors; 4 . the different somatostatin analogs used [36]; 5. differences in dosages; 6 . different modes of administration. Treatment with somatostatin analogs may cause different endocrine effects in the various models. As in our present study, the number of animals and experiments used might influence definite conclu- sions. Of paramount importance might be the presence of somatostatin receptors required for direct growth inhibitory effects. Schally's group demonstrated somatostatin receptors in MXT mouse mammary carcinoma [35], while we could not demonstrate these receptors in the DMBA-induced mammary tumors. In their experiments, the microcapsules containing the somatostatin analog RC-160 liberated $25 \mu \mathrm{g}$ per day, a dose not different from the highest sandostatin dose in the present study. In a transplantable pancreatic tumor model we observed no difference in antitumor efficacy of equal dosages of RC-160 and sandostatin, with both drugs administered by daily injections [37]. Therefore, besides the presence of somatostatin receptors in their tumor model, the better results reported by Szende et al. [35] might also be explained by the mode of drug administration (microcapsules vs. daily injections). Continuous administration of hormone analogs by implants [23] or microcapsule formulations [35] proved to be more effective than daily injections, as also concluded by Szende et al. [35]. In fact, with respect to LHRH analogs, we found increased plasma gonadotropin levels after treatment with buserelin injections, whereas decreased levels were caused by implants [23]. Also, a delayed release formulation of the somatostatin analog RC-160 appeared more inhibitory towards PRL secretion than i.v. injection of the drug [38].

Regarding human breast cancers, direct growth inhibitory effects of somatostatin analogs are possible in view of the presence of somatostatin receptors in one-sixth up to one-half of tumor samples. In continuation of our initial report [39], we have found somatostatin receptors in $15 \%$ of 110 human primary breast tumors by autoradiography [19]. This percentage is higher, when fresh and larger tumor specimens are used [40]. Papotti et al. [41] demonstrated somatostatin receptors in $17 \%$ of 100 breast tumors, and observed a significant relationship with expression of neuroendocrine markers. Fekete et al. [42] found somatostatin receptors in even $36 \%$ of 178 biopsy samples by biochemical methods. In our experience, patients with somatostatin receptor-positive breast tumors have a better prognosis than patients with somatostatin recep- 
tor-negative tumors [19]. Antitumor effects of sandostatin treatment on growth of human breast cancer cells have been demonstrated in vitro [21] and in nude mice [43]. In patients with metastatic breast cancer significant endocrine effects have been demonstrated due to chronic sandostatin treatment, suggesting also the possibility of indirect endocrine inhibition of tumor growth [44, 45, 46]. However, thus far, the antitumor effects in these two phase II studies were disappointing. Manni et al. [44, 45] observed a tumor response in only 1 out of 10 patients, whereas Vennin et al. [46] observed stable disease for longer than three months in only 3 out of 14 evaluable patients. These relatively poor results might be explained by the fact that all patients were heavily pretreated and that other growth stimulatory hormones were not antagonized. Therefore, for more definite conclusions on the value of somatostatin analog traeatment in breast cancer we need more (randomized) trials.

\section{Acknowledgements}

This study was financially supported by grant RRTI $85-15$ of The Dutch Cancer Society. The supply of sandostatin (SMS201-995) by Sandoz Ltd, Basel, Switzerland, and of buserelin by Hoechst (Dr J. Sandow), Frankfurt am Main, F.R.G., is gratefully acknowledged. We thank $\mathrm{Mr}$ P. Uitterlinden for his excellent technical assistance.

\section{References}

1. Lawson DM, Sensui N, Haisenleder DH, Kaufman PN, Gala RR: Prolactin levels and molecular heterogeneity in rat strains with high and low incidence of DMBA-induced mammary tumors. Breast Cancer Res Treat 4: 129-136, 1984

2. Nicholson RI, Walker KJ, Davies P: Hormone agonists and antagonists in the treatment of hormone sensitive breast and prostate cancer. Cancer Surv 5: 463-486, 1986

3. Bruning PF: Prolactin and breast cancer. In: Klijn JGM, Paridaens R, Foekens JA (eds) Hormonal Manipulation of Cancer: Peptides, Growth Factors and New (Anti)steroidal
Agents. EORTC Monograph Series, Raven Press, New York, vol 18: 167-173, 1987

4. L'Hermite-Balériaux M, Casteels S, L'Hermite M: Prolactin receptors in breast cancer: importance of the membrane preparation: In: Klijn JGM, Paridaens R, Foekens JA (eds) Hormonal Manipulation of Cancer: Peptides, Growth Factors and New (Anti)steroidal Agents. EORTC Monograph Series, Raven Press, New York, vol 18: 157-165, 1987

5. Peyrat JP, Djiane J, Kelly PA, Vandewalle B, Bonneterre $\mathrm{J}$, Demaille A: Characterization of prolactin receptors in human breast cancer. Breast Cancer Res Treat 4: 275-281, 1984

6. Murphy LJ, Murphy LC, Vrhovsek E, Sutherland RL, Lazarus L: Correlation of lactogenic receptor concentration in human breast cancer with estrogen receptor concentration. Cancer Res 44: 1963-1968, 1984

7. Murphy LJ, Vrhovsek E, Sutherland RL, Lazarus L: Growth hormone binding to cultured human breast cancer cells. J Clin Endocrinol Metab 58: 149-156, 1984

8. Emerman JT, Leaky M, Gout PW, Bruchovsky N: Elevated growth hormone levels in sera from breast cancer patients. Horm Metab Res 17: 421-424, 1985

9. Pierrepoint CG, Turkes AO, Walker KJ, Harper ME, Wilson DW, Peeling WB, Griffiths K: Endocrine factors in the treatment of prostatic cancer. In: Schroeder FH, Richards B (eds) Therapeutical Principles in Metastatic Prostatic Cancer, Alan R. Liss, New York, 1985, pp 51-72

10. Davoren JB, Hsueh AJW: Growth hormone increases ovarian levels of immunoreactive somatomedin C/insulinlike growth factor-1 in vivo. Endocrinol 118: 888-890, 1986

11. Goustin AS, Leof EB, Shipley GD, Moses HL: Growth factors and cancer. Cancer Res 46: 1015-1029, 1986

12. Schally AV, Redding TW, Cai RZ, Paz JI, Ben-David M, Comaru-Schally AM: Somatostatin analogs in the treatment of various experimental tumors. In: Klijn JGM, Paridaens R, Foekens JA (eds) Hormonal Manipulation of Cancer: Peptides, Growth Factors, and New (Anti)steroidal Agents. EORTC Monograph Series, Raven Press, New York, vol 18: 431-441, 1987

13. Schally AV: Oncological applications of somatostatin analogs. Cancer Res 48: 6977-6985, 1988

14. Lamberts SWJ, Krenning EP, Klijn JGM, Reubi JC: The clinical use of somatostatin analogs in the treatment of cancer. Baillière's Clinical Endocrinology and Metabolism 3: 29-49, 1990

15. Lippman ME: Growth regulation of human breast cancer. Clin Res 83: 375-382, 1985

16. Pekonen F, Partanen S, Makinen T, Rutanen EM: Receptors for epidermal growth factor and insulin-like growth factor- 1 and their relation to steroid receptors in human breast cancer. Cancer Res 48: 1343-1347, 1988

17. Peyrat JP, Bonneterre J, Beuscart R, Djiane J, Demaille A: Insulin-like growth factor-1 receptors in human breast cancer and their relation to estradiol and progesterone receptors. Cancer Res 48: 6429-6433, 1988

18. Foekens JA, Portengen H, Janssen M, Klijn JGM: Insulin- 
like growth factor-1 (IGF-1) receptors and IGF-1-like activity in human primary breast cancer. Cancer 63: 2139-2147, 1989

19. Foekens JA, Portengen H, Van Putten WLJ, Trapman AMAC, Reubi JC, Alexieva-Figusch J, Klijn JGM: The prognostic value of receptors for insulin-like growth factor-1, somatostatin, and epidermal growth factor in human breast cancer. Cancer Res 49: 7002-7009, 1989

20. Klijn JGM, Portengen H, Van Putten WLJ, Trapman AMAC, Reubi JC, Alexieva-Figusch J, Foekens JA: The prognostic value of receptors for somatostatin, insulin-like growth factor (IGF-1) and epidermal growth factor (EGF) in human breast cancer. In: Proceedings of the 25th Annual Meeting of the American Society of Clinical Oncology, p21, abstract 78, 1989

21. Setyono-Han B, Henkelman MS, Foekens JA, Klijn JGM: Direct inhibitory effects of somatostatin (analogs) on the growth of human breast cancer cells. Cancer Res 47: 15661570,1987

22. Klijn JGM, Setyono-Han B, Bakker GH, Henkelman MS, Portengen $\mathrm{H}$, Foekens JA: Effects of somatostatin analog (sandostatin) treatment in experimental and human cancer. In: Klijn JGM, Paridaens R, Foekens JA (eds) Hormonal Manipulation of Cancer: Peptides, Growth Factors and New (Anti)steroidal Agents. EORTC Monograph Series, Raven Press, New York, vol 18: 459-468, 1987

23. Bakker GH, Setyono-Han B, Portengen H, De Jong FH, Foekens JA, Klijn JGM: Endocrine and antitumor effects of combined treatment with an antiprogestin and an antiestrogen or an LHRH-agonist in female rats bearing mammary tumors. Endocrinol 125: 1593-1598, 1989

24. Lamberts SWJ, Reubi JC, Uitterlinden P, Zuiderwijk J, Van den Werff P, Van Hal P: Studies on the mechanism of action of the inhibitory effect of somatostatin analog SMS201-995 on the growth of the prolactin/adrenocorticotropin-secreting pituitary tumor 7315a. Endocrinol 118: 2188-2194, 1986

25. Blankenstein MA, Peters-Mechielsen MJ, Mulder E, Van der Molen HJ: Estimation of the total estrogen receptors in DMBA-induced rat mammary tumors by exchange of nuclear bound ligand at low temperature: a comparison with rat uterus. J Steroid Biochem 13: 557-564, 1980

26. EORTC Breast Cancer Cooperative Group. Revision of the standards for the assessment of hormone receptors in human breast cancer. Eur J Cancer 16: 1513-1515, 1980

27. Reubi JC, Heitz PU, Landolt AM: Visualization of somatostatin receptors and correlation with immunoreactive growth hormone and prolactin in human pituitary adenomas: evidence for different tumor subclasses. J Clin Endocrinol Metab 65: 65-73, 1987

28. Reubi JC, Haecki WH, Lamberts SWJ: Hormone-producing gastrointestinal tumors contain a high density of somatostatin receptors. J Clin Endocrinol Metab 65: 1127-1134, 1987

29. Reubi JC, Probst A, Cortes R, Palacios JM: Distinct topo- graphical localization of two somatostatin receptor subpopulations in the human cortex. Brain Res 406: 391-396, 1987

30. Welschen R, Osman P, Dullaart J, De Greef WJ, Uilenbroek JThJ, De Jong FH: Levels of follicle-stimulating hormone, luteinizing hormone, oestradiol-17 $\beta$ and progesterone, and follicular growth in the pseudopregnant rat. J Endocrinol 64: 37-47, 1975

31. Millar RP, Klaff LJ, Barron J, Levitt NS, Luig N: Somatostatin-28 inhibits LHRH-stimulated gonadotropin secretion in man. Clin Endocrinol 17: 103-107, 1982

32. Chiodera P, Volpi R, d'Amato L, Fatone M, Cigarini C, Fava A, Caiazza A, Rossi G, Covio V: Inhibition by somatostatin of LHRH-induced LH release in normal menstruating women. Gynecol Obstet Invest 22: 17--21, 1986

33. Schally AV, Redding TW: Somatostatin analogs as adjuncts to agonists of luteinizing hormone-releasing hormone in the treatment of experimental prostate cancer. Proc Natl Acad Sci USA 84: 7275-7279, 1987

34. Rose DP, Gottardis M, Noonan J\}: Rat mammary carcinoma regressions during suppression of serum growth hormone and prolactin. Anticancer Res 3: 323-326, 1983

35. Szende B, Lapis K, Redding TW, Srkalovic G, Schally AV: Growth inhibition of MXT mammary carcinoma by enhancing programmed cell death (apoptosis) with analogs of luteinizing hormone-releasing hormone and somatostatin. Breast Cancer Res Treat 14: 307-314, 1989

36. Liebow C, Reilly C, Serrano M, Schally AV: Somatostain analogs inhibit growth of pancreatic cancer by stimulating tyrosine phosphatase. Proc Natl Acad Sci USA 86: 20032007, 1989

37. Klijn JGM, Setyono-Han B, Bakker GH, Foekens JA: Dose-effect finding studies on endocrine parameters and tumor growth by the somatostatin analog RC-160 in rat pancreatic tumors. Program and abstracts of the Sixth NCIEORTC Symposium on new Drugs in Cancer Therapy, Amsterdam, abstract 241, 1989

38. Bokser L, Schally AV: Delayed release formulation of the somatostatin analog RC-160 inhibits the growth hormone (GH) response to $\mathrm{GH}$-releasing factor-(1-29)- $\mathrm{NH}_{2}$ and decreases elevated prolactin levels in rats. Endocrinol 123: $1735-1739,1988$

39. Reubi JC, Maurer R, Van Werder K, Torhorst J, Klijn JGM, Lamberts SWJ: Somatostatin receptors in human endocrine tumors. Cancer Res 47: 551-558, 1987

40. Reubi JC, Waser B, Foekens JA, Klijn JGM, Lamberts SWJ, Laissue J: Somatostatin receptor incidence and distribution in breast cancer using receptor autoradiography: relationship to EJF receptors. Int J Cancer 46: 416-420, 1990

41. Papotti M, Maci L, Bussolati G, Reubi JC: Correlative study on neuro-endocrine differentiation and presence of somatostatin receptors in breast carcinomas. Int J Cancer 43: 365-370, 1989

42. Fekete M, Wittliff JL, Schally AV: Characteristics and distribution of receptors for [D-Trp $\left.{ }^{6}\right]$-luteinizing hormonereleasing hormone, somatostatin, epidermal growth factor, 
and sex steroids in 500 biopsy samples of human breast cancer. J Clin Lab Anal 3: 137-141, 1989

43. Weber C, Merriam L, Koschitzky T, Karp F, Benson M, Forde K, LoGerfo P: Inhibition of growth of human breast carcinomas in vivo by somatostatin analog SMS 201-995: treatment of nude mouse xenografts. Surgery 106: 416-422, 1989

44. Manni A, Boucher AE, Harvey H, Lipton A, Simmonds M: Combined somatostatin analog and bromocriptine therapy in the treatment of advanced breast cancer. Program and abstracts, The Endocrine Society, New Orleans, abstract $1328,1988, \mathrm{p} 352$
45. Manni A, Boucher AE, Demers LM, Harvey HA, Lipton A, Simmonds MA, Bartholomew M: Endocrine effects of combined somatostatin analog and bromocriptine therapy in women with advanced breast cancer. Breast Cancer Res Treat 14: 289-298, 1989

46. Vennin PH, Peyrat JP, Bonneterre J, Louchez MM, Harris AG, Demaille A: Effect of the long-acting somatostatin analog SMS201-995 (sandostatin) in advanced breast cancer. Anticancer Res 9: 153-156, 1989 